\title{
A gradient of mercury concentrations in Scottish single malt whiskies
}

Neil L Rose*, Handong Yang, Simon D Turner

Environmental Change Research Centre, Department of Geography, University College London, Gower Street, London WC1E 6BT UK.

*author for correspondence: n.rose@ucl.ac.uk

\begin{abstract}
Mercury $(\mathrm{Hg})$ concentrations were measured in 26 Scottish single malt whiskies and all found to be very low $\left(<10 \mathrm{ng} \mathrm{L}^{-1}\right)$, posing no threat to human health through reasonable levels of consumption. However, a significant south-to-north declining gradient in $\mathrm{Hg}$ concentrations was observed reflecting that reported for atmospheric deposition. We speculate that this gradient could be due to a combination of contemporary deposition and the legacy of industrial mercury emissions and deposition over the last 200 years affecting concentrations in local waters used in whisky production. As UK atmospheric emissions of mercury have declined by $90 \%$ since the 1970 s, we suggest that whisky being produced today should have even lower $\mathrm{Hg}$ concentrations when consumed in $10-15$ years time. This reduction may be compromised by the remobilisation of contaminants stored in catchment soils being transferred to source waters, but is very unlikely to raise the negligible health risk due to $\mathrm{Hg}$ from Scottish single malt whisky consumption.
\end{abstract}

Keywords: atmospheric deposition; human health; mercury; whisky 


\section{Introduction}

Almost two decades ago, Kleinjans et al. (1996) reported on polycyclic aromatic hydrocarbon (PAH) concentrations for a range of Scottish and Irish whiskies and American Bourbons, demonstrating that Scottish malts contained the highest concentrations of these carcinogenic compounds, albeit rather low when compared to smoked and char-broiled foods. Although sample numbers for Scottish malt whiskies in the study were very low $(\mathrm{N}=6)$ and the authors made no reference to the geographical distribution of the PAH concentrations in their article, it was widely reported that Scottish whiskies from the west coast had the highest carcinogenic potential expressed as benzo[a]pyrene equivalents. This publication understandably caused considerable discontent especially with the Scottish Whisky Association (Hunt 1996).

The authors of the study (Kleinjans et al. 1996) suggested that the source of the PAH may be derived from the drying of germinated barley over a "peat-fuelled furnace" and / or from the storage of the spirit in charred barrels over many years. However, they neither gave any explanation as to why these processes might result in higher values for Scottish single malt whiskies over (for example) Scottish blended whiskies, nor why these processes should result in higher PAH content on the west coast of Scotland compared to elsewhere. Given the widely reported gradient of pollutant deposition across Scotland from south-to-north including fossil-fuel derived pollutants (Rose and Juggins 1994), vehicle emissions (e.g. $\mathrm{NO}_{2}$ ) and acidifying substances (e.g. total oxidised sulphur - $\mathrm{SO}_{\mathrm{x}}$; total oxidised nitrogen - NO ) (RoTAP 2012) it is conceivable that the spatial distribution of PAH observed in Scottish malt whiskies also includes a component derived from atmospheric pollution deposition or the legacy of it.

To consider this possibility further we measured mercury $(\mathrm{Hg})$ in a range of Scottish single malt whiskies. Mercury deposition exhibits a declining gradient across Scotland from south-to-north (RoTAP 2012) and in the environment is known to behave in a similar manner to organic compounds (Braune et al. 2005), such as PAHs, including a potential to biomagnify in both terrestrial (e.g. Rimmer et al. 2010) and aquatic food webs (e.g. Clayden et al. 2013). Mercury shares some sources (e.g. coal combustion) with PAHs and there are similarly well-known health concerns. It is a potent neurotoxicant (e.g. Davidson et al. 2004; Mergler et al. 2007) with the developing human brain particularly susceptible to injury (Choi and Grandjean 2008) and as a consequence women of childbearing age are considered an especially vulnerable population (WHO 2013). A Provisional Tolerable Weekly Intake (PTWI) value of $1.6 \mu \mathrm{g} \mathrm{kg}^{-1}$ body weight (bw) has been set for methylmercury and $4 \mu \mathrm{g}$ $\mathrm{kg}^{-1}$ bw for inorganic mercury (WHO 2003, 2010). 


\section{Methods}

Twenty-six Scottish single malt whiskies were selected for analysis. As in the PAH study (Kleinjans et al. 1996), these whiskies were purchased 'off the shelf', were all $9-15$ years old and contained no cask strength samples or special 'wood finishes'. All the Scottish whiskies in the original PAH study were included in the analysis and at least two samples from each of the 11 geographical regions defined by Lapointe and Legendre (1994) in their organoleptic (e.g. smell, taste, appearance) classification of Scottish single malts. This geographical range covered samples from Galloway (Bladnoch) in the south-west of Scotland to the Orkney Islands (Highland Park) off the north coast and from Islay in the Inner Hebrides (Bowmore, Ardbeg, Laphroaig) to Glen Garioch in the east.

The method for $\mathrm{Hg}$ analysis was adapted from the US EPA Method 1631 for mercury in water (US EPA 2002). To each $25 \mathrm{~mL}$ whisky sample, $0.25 \mathrm{~mL}$ concentrated $\mathrm{HCl}$ (Romil; pure grade) and $0.25 \mathrm{~mL}$ purified $0.1 \mathrm{~N} \mathrm{BrO}_{3}{ }^{-} / \mathrm{Br}^{-}$were added and sealed for 30 minutes. $15 \mu \mathrm{L} 12 \% \mathrm{NH}_{2} \mathrm{OH} \cdot \mathrm{HCl}$ was then added and the samples diluted to $50 \mathrm{~mL}$ with distilled deionised water. $\mathrm{Hg}$ analysis was by gold trap cold vapour-atomic fluorescence spectrometry (CV-AFS) following reduction with $\mathrm{SnCl}_{2}$. A certified reference mercury standard (TraceCERT ${ }^{\circledast}$, Sigma-Aldrich: $1000 \mathrm{ng} \mathrm{L}^{-1} \pm 4 \mathrm{ng} \mathrm{L}^{-1}$ in $12 \%$ nitric acid) was used to produce standard solutions. Quality control blanks were measured after every three samples to monitor measurement stability. The analytical limit of detection was $0.6 \mathrm{ng} \mathrm{L}^{-1}$. Measurement errors for $\mathrm{Hg}$ were $\pm 0.4 \mathrm{ng} \mathrm{L}^{-1}$.

\section{Results and Discussion}

Mercury concentrations and health risk

All Hg concentrations were very low (Figure 1). Eight of the samples, mainly to the east and north of Scotland, were below the analytical limit of detection. The highest $\mathrm{Hg}$ concentration was $9.5 \mathrm{ng} \mathrm{L}^{-1}$ for Bladnoch in Galloway, while Laphroaig, which showed the highest PAH concentrations, was second highest $\left(4.6 \mathrm{ng} \mathrm{L}^{-1}\right)$. The four highest concentrations $\left(>2.7 \mathrm{ng} \mathrm{L}^{-1}\right)$ were all in the south and west with the mean concentration for the three Islay whiskies being $3.1 \mathrm{ng} \mathrm{L}^{-1}$. These low $\mathrm{Hg}$ concentrations are in agreement with the only other reported analysis to our knowledge (Lima et al. 1973) where $\mathrm{Hg}$ in a whisky of unknown provenance was recorded as 'not detected' (detection limit also unfortunately not stated).

The highest $\mathrm{Hg}$ concentration of $9.5 \mathrm{ng} \mathrm{L}^{-1}$ is more than 600 times lower than the World Health Organisation guideline value for drinking water $\left(6 \mu \mathrm{g} \mathrm{L^{-1 }}\right.$ based on a $60 \mathrm{~kg}$ person drinking 2 litres of 
water a day) (WHO 2005). Furthermore, these whisky Hg concentrations are similar to, or below, remote Scottish mountain lake water concentrations $\left(5-21 \mathrm{ng} \mathrm{L}^{-1}(1997-2005)\right.$ at Lochnagar above the Royal Lochnagar distillery; 14 on Figure 1), lower than bulk rainfall Hg concentrations over the same period in the same location ( $12-35 \mathrm{ng} \mathrm{L}^{-1}$ ) (Yang et al. 2002 and unpublished data) and similar to annual volume weighted mean concentrations for deposition at the two $\mathrm{Hg}$ monitoring sites in Scotland at Auchenforth Moss south of Edinburgh (2.5 ng L-1) and Banchory in Aberdeenshire (2.8 ng $\mathrm{L}^{-1}$ ) between 2005 and 2009 (Rowland et al. 2010). Therefore, from the perspective of personal $\mathrm{Hg}$ exposure, there would appear to be no health risk from responsible Scottish malt whisky consumption.

\section{Spatial distribution}

With the four highest $\mathrm{Hg}$ concentrations all to the south and west of Scotland the spatial distribution would appear to be similar to that of $\mathrm{Hg}$ in atmospheric deposition (RoTAP 2012) and also of other atmospherically deposited contaminants derived from fossil-fuel combustion such as spheroidal carbonaceous fly-ash particles (SCPs), a by-product of industrial coal and oil combustion (Rose and Juggins 1994). It is also similar to the distribution suggested for PAHs although we stress the caveat that sample numbers are low in both studies. While the spatial autocorrelation of these data are random (Global Moran's I, z=1.21, p=0.22) the dataset $z$-score and Hot Spot (Getis-Ord Gi) values support a south to north gradient in Hg concentrations (Getis and Ord 1992). (Figure 2).

If this $\mathrm{Hg}$ distribution is 'real' it is interesting to speculate on possible causes. Available information indicates that the barrels used for long-term maturation are similar for all whiskies (mainly European or American oak and previously used for sherry or bourbon) and so are unlikely to cause the observed distribution. Similarly, neither age of maturation nor storage container (four were supplied in plastic rather than glass bottles) appeared to have any relationship with $\mathrm{Hg}$ concentration. However, water sources for all distilleries are reported as being from local springs, lochs and burns (scotchwhisky.net 2014) and therefore, if $\mathrm{Hg}$ concentrations in these source waters reflect the concentration gradient for $\mathrm{Hg}$ in atmospheric deposition then it may be that the water used in whisky production is a contributing factor influencing the pattern observed for $\mathrm{Hg}$ in the whiskies. This being the case, it would then also be expected that a similar gradient would exist for other atmospherically deposited contaminants that exhibit a depositional gradient across the country including lead (Pb), zinc ( $\mathrm{Zn}$ ), vanadium (V) and antimony (Sb) (Harmens et al. 2010). Further work is required to confirm this. 
Supporting evidence from $\mathrm{Hg}$ measurements for Scottish waters and deposition is rather scarce. Data from the two monitoring sites at Auchenforth Moss and Banchory are available from 2005 2013 (Rowland et al. 2010; Defra 2015a) and show very similar concentrations over the period and no temporal trend. The data from these two sites are included in UK Hg rain concentration maps (Defra 2015b) showing rather limited information across Scotland, and wet deposition maps (mg ha-1 $\mathrm{yr}^{-1}$ ) which are driven by rainfall patterns and therefore show high deposition in the west declining to the east. This spatial pattern is also reported in Rowland et al (2010). Mercury data for Scottish surface waters from the Scottish Government's Marine Scotland Freshwater Laboratory is sporadic for both sampling sites and sampling period between 1998 and 2007 (A. McCartney, Marine Scotland, pers. comm.). Many of these measurements are below the limit of detection but the remainder may show a declining trend with latitude for some years although this tends to be driven by a few high values in the south, principally some inflowing streams to Loch Grannoch in Galloway. Conversely, trends in mercury concentrations at the river-basin scale across Scotland appear to show the opposite pattern with lower concentrations in the south and west of the country and higher values in the north (Anderson et al. 2010), suggested as being due to trends in organic carbon in these waters. Without a systematic monitoring programme for $\mathrm{Hg}$ in Scottish surface waters, and with only two sites monitoring $\mathrm{Hg}$ in deposition across the country, there are insufficient data to support our hypothesis that the $\mathrm{Hg}$ gradient we observe in single malt whiskies can be related to $\mathrm{Hg}$ in source waters. This must remain speculative until further data are available.

Finally, we should consider that as all these whiskies are 9-15 years old if the observed gradient in $\mathrm{Hg}$ is reflecting spatial trends in deposition then this is not the pattern of current deposition, but rather that of a decade or two ago. Mercury emissions have reduced by over $90 \%$ since the 1970 s (NAEI 2014) and so if $\mathrm{Hg}$ in single malt Scottish whisky is reflecting the scale and extent of $\mathrm{Hg}$ in atmospheric deposition, then we might expect 'old' whisky produced in the 1960s and 1970s to have higher $\mathrm{Hg}$ concentrations (but a similar declining gradient south-to-north) as $\mathrm{Hg}$ emissions and deposition peaked at that time. Conversely, we might expect $\mathrm{Hg}$ concentrations in whisky being produced today (to be consumed in $10-15$ years time) to have even lower $\mathrm{Hg}$ concentrations than those observed in our study. However, this latter point is complicated by the possibility of climate enhanced remobilisation of legacy pollutants whereby trace metals such as $\mathrm{Hg}$ and $\mathrm{Pb}$ and, by inference, other atmospherically deposited pollutants (including organic compounds such as PAHs), previously deposited and stored in catchment soils are becoming available to surface waters (Yang et al. 2002; Rose et al. 2012). Therefore, future concentrations of contaminants in whiskies may reflect remobilised, historically deposited contamination, stored within soils and draining into local 
water sources rather than contemporary atmospheric deposition at the time of whisky manufacture. Even so, as we have observed, concentrations of $\mathrm{Hg}$ would have to drastically increase for there to be any risk at all to human health from this source.

\section{Conclusions}

Mercury concentrations in Scottish single malt whiskies are all very low and pose no threat to human health through reasonable levels of consumption. Concentrations are at, or below, those observed in remote Scottish mountain lake waters and deposition. However, although low, we observe a significant gradient in $\mathrm{Hg}$ with declining concentrations from south-to-north, which may reflect $\mathrm{Hg}$ deposited from the atmosphere and draining into the local source waters used in whisky manufacture. If true, we speculate that (i) this pattern should also be observed in other atmospherically deposited contaminants and, (ii) $\mathrm{Hg}$ in whisky should further decline in future as emissions continue to decrease. However, legacy contamination, re-mobilised from storage within catchments and exacerbated by predicted climatic changes, could negate or even reverse this decline but despite this are very unlikely to raise the health risk due to $\mathrm{Hg}$ from Scottish whisky consumption.

\section{Acknowledgements}

We thank scientists from the Scottish Environment Protection Agency (W. Duncan; J. Best); Scottish Natural Heritage (I. Sime); the UK Environmental Change Network (D. Monteith) and the UK Centre for Ecology and Hydrology (A. Lawlor) for their help in trying to trace mercury data for surface waters and deposition in Scotland. In particular, we thank Alistair McCartney and lain Malcolm (Freshwater Laboratory, Marine Scotland) for providing access to the data they hold. We also thank three anonymous reviewers for their suggestions on improving the manuscript.

\section{References}

Anderson, H., Futter, M., Oliver, I, Redshaw J. \& Harper A. (2010). Trends in Scottish river water quality. Scottish Environment Protection Agency. 178 pp.

Braune, B.M., Outridge, P.M., Fisk, A.T., Muir, D.C.G., Helm, P.A., Hobbs, K., Hoekstra, P.F., Kuzyk, Z.A., Kwan, M., Letcher, R.J., Lockhart, W.L., Norstrom, R.J., Styren, G.A. \& Stirling, I. (2005) 
Persistent organic pollutants and mercury in marine biota of the Canadian Arctic: An overview of spatial and temporal trends. Science of the Total Environment, 351-352, 4-56.

Choi, A.L. \& Grandjean, P. (2008). Methylmercury exposure and health effects in humans. Environmental Chemistry, 5, 112-120.

Clayden, M.G., Kidd, K.A., Wyn, B., Kirk, J.L., Muir, D.C.G. \& O’Driscoll, N.J. (2013). Mercury biomagnification through food webs is affected by physical and chemival characteristics of lakes. Environmental Science and Technology 47, 12047-12053.

Davidson, P.W., Myers, G.J. \& Weiss, B. (2004) Mercury exposure and child development outcomes. Pediatrics, 113, 1023-1029.

Department for Environment, Food and Rural Affairs (2015a). Data archive webpage. http://ukair.defra.gov.uk/data/. Accessed $15^{\text {th }}$ March 2015.

Department for Environment, Food and Rural Affairs (2015b). UK Pollutant deposition maps. http://pollutantdeposition.defra.gov.uk/image/tid/47?page=1 Accessed 15 th March 2015.

Getis, A., \& Ord, J. K. (1992). The analysis of spatial association by use of distance statistics. Geographical Analysis, 24, 189-206.

Harmens, H., Norris, D. A., Steinnes, E., Kubin, E., Piispanen, J., Alber, R., Aleksiayenak, Y., Blum, O., Coşkun, M., Dam, M., De Temmerman, L., Fernández, J. A., Frolova, M., Frontasyeva, M., González-Miqueo, L., Grodzińska, K., Jeran, Z., Korzekwa, S., Krmar, M., Kvietkus, K., Leblond, S., Liiv, S., Magnússon, S. H., Maňkovská, B., Pesch, R., Rühling, Å., Santamaria, J. M., Schröder, W., Spiric, Z., Suchara, I., Thöni, L., Urumov, V., Yurukov,a L., \& Zechmeister, H. G. (2010) Mosses as biomonitors of atmospheric heavy metal deposition: Spatial patterns and temporal trends in Europe. Environmental Pollution 158, 3144-3156.

Hunt, L. (1996) Whisky warning brings unseasonal anger. The Independent 20 th December 1996. http://www.independent.co.uk/news/whisky-warning-brings-unseasonal-anger-1315287.html. Accessed $11^{\text {th }}$ December 2014.

Kleinjans, J. C., Moonen, E. J. C., Dallinga, J. W., Albering, H.J., van den Bogaard, A.E.J.M. \& van Schooten, F-J. (1996) Polycyclic aromatic hydrocarbons in whiskies. The Lancet 348, 1731 Lapointe, F-J. \& Lagendre, P. A classification of pure malt scotch whiskies. (1994) Applied Statistics 43, 237-257.

Lima, F. W., Silva, C. M., \& Guimarães, R. (1973) An actual case of examination of counterfeited whisky. Journal of Radioanalytical Chemistry 15, 157-164.

Mergler, D., Anderson, H. A., Chan, L. H. M., Mahaffey, K. R., Murray, M., Sakamoto, M., \& Stern, A. H. (2007) Methylmercury exposure and health effects in humans: A worldwide concern. Ambio 36, 3-11. 
National Atmospheric Emissions Inventory http://naei.defra.gov.uk/ Accessed 24 ${ }^{\text {th }}$ Oct 2014.

Rimmer, C.C., Miller,E.K., McFarland,K.P., Taylor,R.J. \& Faccio, S.D. (2010) Mercury bioaccumulation and trophic transfer in the terrestrial food web of a montane forest. Ecotoxicology. 19, 697709

Rose N.L. \& Juggins S. (1994) A spatial relationship between carbonaceous particles in lake sediments and sulphur deposition. Atmospheric Environment 28, 177-183.

Rose N. L., Yang H., Turner S. D. \& Simpson G. L. (2012) An assessment of the mechanisms for the transfer of lead and mercury from atmospherically contaminated organic soils to lake sediments with particular reference to Scotland, UK. Geochimica et Cosmochimica Acta 82, 113-135.

RoTAP. Review of Transboundary Air Pollution: Acidification, Eutrophication, Ground Level Ozone and Heavy Metals in the UK. 2012. Contract Report to the Department for Environment, Food and Rural Affairs. Centre for Ecology \& Hydrology.

Rowland A.P., Lawlor, A.J., Guyatt H.J. and Wadsworth R.A. (2010). Background wet deposition of mercury in Great Britain. Journal of Environmental Monitoring 12, 1747-1755.

Scotchwhisky.net. www.scotchwhisky.net. Accessed 20

United States Environmental Protection Agency (2002). Method 1631, Revision E: Mercury in water by oxidation, purge and trap, and cold vapour atomic fluorescence spectrometry. http://water.epa.gov/scitech/methods/cwa/metals/mercury/index.cfm.

World Health Organisation (2003) Joint FAO/WHO Expert Committee on Food Additives. $61^{\text {st }}$ meeting. Rome, 10-19 June 2003. www.who.int/entity/mediacentre/news/notes/2003/np20/en/. Accessed $17^{\text {th }}$ December 2014.

World Health Organisation. (2005) Mercury in drinking water. Background document for development of WHO guidelines for drinking-water quality. http://www.who.int/water sanitation health/dwq/chemicals/mercuryfinal.pdf Accessed $20^{\text {th }}$ Oct 2014.

World Health Organisation (2010) Joint FAO/WHO Expert Committee on Food Additives. $72^{\text {nd }}$ meeting. Rome, 16-25 February 2010. www.who.int/foodsafety/chem/summary72 rev.pdf Accessed $17^{\text {th }}$ December 2014.

World Health Organisation (2013) World Health Organisation welcomes international treaty on mercury. http://www.who.int/mediacentre/news/statements/2013/mercury 20130119/en/

Yang H., Rose N. L., Battarbee R. W. \& Boyle, J.F. (2002). Mercury and lead budgets for Lochnagar, a Scottish mountain lake and its catchment. Environmental Science and Technology 36, 13831388. 
Figure 1. Concentrations of mercury in Scottish whiskies $\left(\mathrm{ng} \mathrm{L}^{-1}\right)$. + represents a concentration below the analytical limit of detection (LOD) $\left(<0.6 \mathrm{ng} \mathrm{L}^{-1}\right)$.

1: Highland Park; 2: Old Pulteney; 3: Glenmorangie; 4: Glen Deveron; 5: Macallan; 6: Aberlour; 7: Glenfiddich; 8: The Singleton; 9: Glenfarclas; 10: Talisker; 11: Glenlivet; 12: Tomatin; 13: Glen Garioch; 14: Royal Lochnagar; 15: Dalwhinnie; 16: Glencadam; 17: Edradour; 18: Tobermory; 19: Aberfeldy; 20: Oban; 21: Auchentoshan; 22: Glenkinchie; 23: Bowmore; 24: Ardbeg; 25: Laphroaig; 26: Bladnoch.

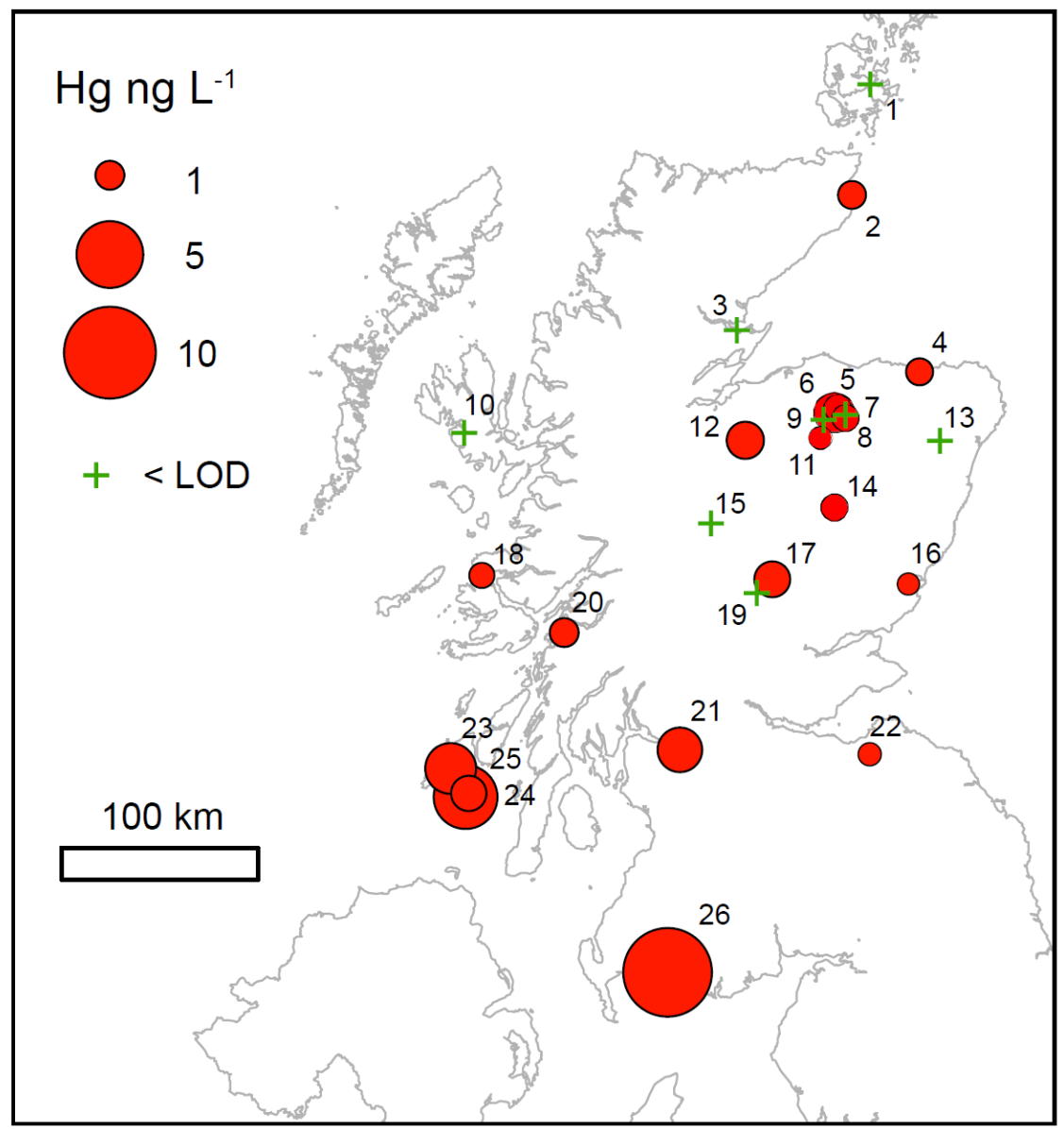


Figure 2. Mercury concentrations in Scottish single malt whiskies plotted against latitude (degrees North). The red line indicates the analytical detection limit. Whiskies with values below this limit of detection are given the nominal value of $0.3 \mathrm{ng} \mathrm{L}^{-1}$ (i.e. half limit of detection). A fitted trend-line is also shown.

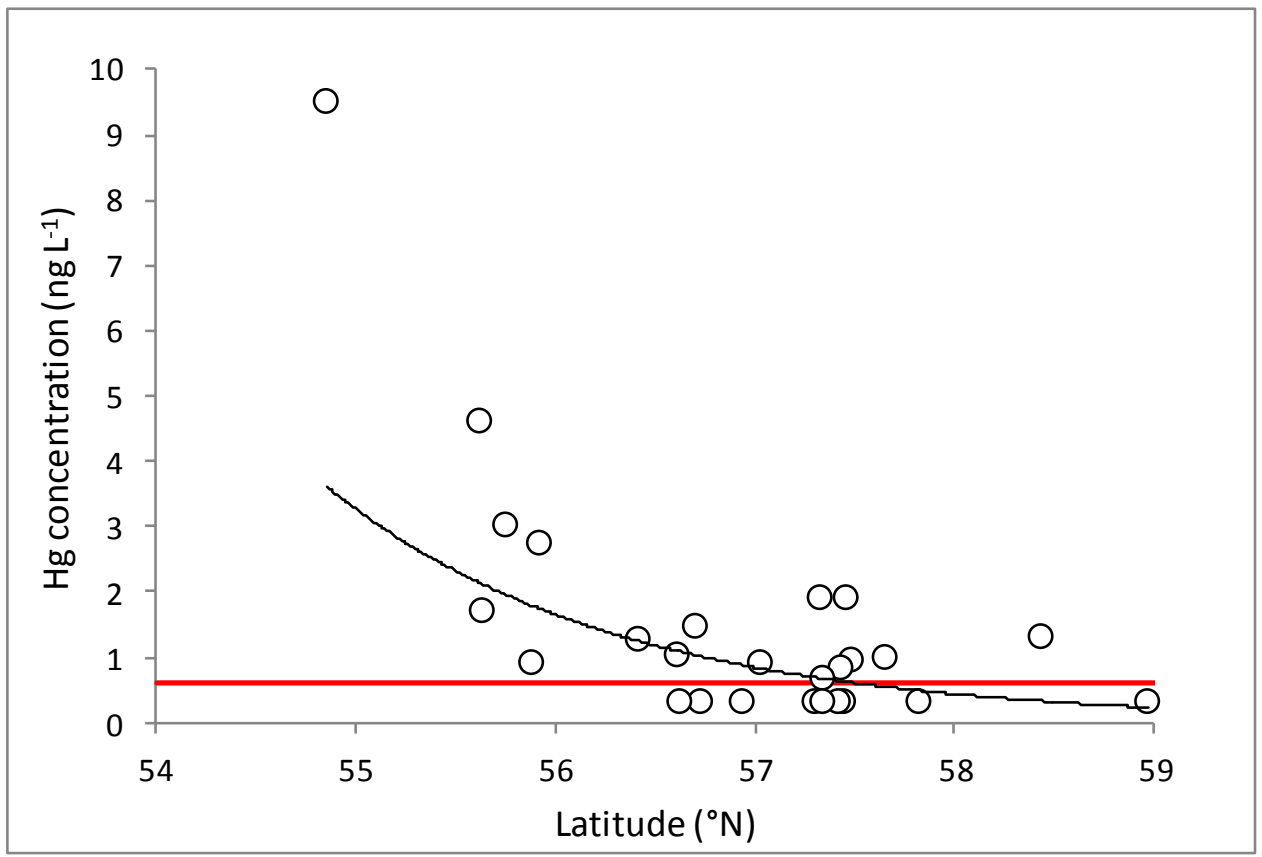

